\title{
THE GREEN MARKETING MIX: A REVIEW OF CUSTOMERS' BODY SHOP PURCHASE INTENTION
}

\author{
Genoveva $^{1}$, Lyliana Levina ${ }^{2}$ \\ ${ }^{1}$ School of Business, President University, Cikarang \\ Email: genoveva@president.ac.id \\ ${ }^{2}$ School of Business, President University, Cikarang
}

Masuk : 03-03-2019, revisi: 17-09-2019, diterima untuk diterbitkan : 30-10-2019

\begin{abstract}
ABSTRAK
Industri kosmetik dan perawatan menyadari bahwa sebagian besar bahan baku dan kemasan produk terdapat kandungan bahan kimia yang dapat mencemari lingkungan. Limbah ini berbahaya dan tidak mudah terurai, sehingga dapat mengancam keanekaragaman hayati. Permasalahan lingkungan ini telah menciptakan permintaan produk ramah lingkungan. The Body Shop adalah salah satu perusahaan yang berhasil menangkap peluang tersebut dan menerapkan strategi pemasaran ramah lingkungan untuk memenuhi harapan konsumen. Penelitian ini bertujuan untuk mengetahui pengaruh bauran pemasaran ramah lingkungan dari The Body Shop® terhadap niat pembelian konsumen. Peneliti menggunakan metode kuantitatif dengan SPSS versi 25 sebagai alat analisis regresi berganda untuk mengetahui signifikansi hubungan antar variabel. Populasi terbatas responden yang berusia 18-24 tahun dan pernah membeli dan menggunakan produk The Body Shop ${ }^{\circledR}$ dari saluran distribusi di Jakarta dalam 1 tahun terakhir. Jumlah sampel dalam penelitian ini adalah 155 responden yang diambil dengan metode purposive sampling non-probabilitas melalui kuesioner online. Para peneliti menemukan bahwa ada pengaruh yang signifikan dari aspek bauran pemasaran ramah lingkungan terhadap niat pembelian konsumen, di mana harga memainkan peran dominan dalam hubungan ini. Bauran pemasaran ramah lingkungan itu sendiri, secara keseluruhan, juga memiliki pengaruh simultan yang signifikan terhadap niat pembelian konsumen. Studi ini menghasilkan informasi yang berguna bagi The Body Shop®, pembaca, dan penelitian di masa depan untuk lebih sadar tentang masalah lingkungan dan penerapan bauran pemasaran ramah lingkungan, juga menyediakan rencana aksi untuk melaksanakan strategi pemasaran ramah lingkungan ini.
\end{abstract}

Kata Kunci: Bauran pemasaran, Niat beli, Produk, Harga, Saluran Distribusi, Promosi

\begin{abstract}
Cosmetics and personal care industry is aware that most of their products' materials, mainly the chemicals content and packaging are polluting the environment. These wastes are hazardous and not easily decomposed, thus it may threaten the biodiversity. Consequently, this environmental issue has created the demand of the enviromental friendly products. The Body Shop ${ }^{\circledR}$ is one of the company who has successfully captured this demand and applied green marketing strategy to fulfill the consumers' expectations. This research intended to find out the influence of green marketing mix of The Body Shop towards consumers' purchase intention. The researcher will use quantitative method with SPSS version 25 as the tool for analysis of multiple regression analysis to reveal the significance relationship between variables. The population will be limited to those who are 18-24 years old and have ever bought and use the The Body Shop ${ }^{\circledR}$ products from Jakarta stores in the past 1 year. The sample size 155 respondends which were drawn with non-probability purposive sampling method through online questionnaire. Researchers found that there is a significant influence of green marketing mix aspects towards consumers' purchase intention, in which green price is playing dominant role in this relationship. The green marketing mix itrself, as a whole, also having a significant simultaneous influence towards consumers' purchase intention. This study resulted in a useful information for The Body Shop ${ }^{\circledR}$, readers, and future research to be more aware about the environmental issue and the implementation of green marketing mix, also providing an action plan to execute this green marketing strategy.
\end{abstract}

Keywords: Green marketing mix, Purcase intention, Product, Place, Promotion 


\section{INTRODUCTION}

\section{Research background}

From Nielsen survey on 2015 which found out that $66 \%$ of respondents would like to pay more for sustainable products that could give positive contribution to the social and environmental change (Sons, 2017). Most companies have successfully captured the consumers' expectations towards green business. Cosmetics and personal care industry is one of the industry that started to implement this kind of concept. This industry is aware that most of their products' ingredients, mainly the chemicals, are polluting the environment, especially water, because the waste comes from the residue after they are being washed down ((Erixon, 2018; Jing \& Songqing, 2011; EPA, 2017). These chemicals are hazardous and not easily decomposed, thus it may threaten the biodiversity (Bogut, 2016).

Currently, Indonesia as a developing country is frequently and easily enables the new cultures and lifestyles enter the country. Lately, cosmetics and personal care products are becoming more common in the society for both men and women due to the high pollution level in the cities and unhealthy lifestyles which bring negative impact to our body and looks (skin, hair, etc.) and creates the needs to taking care of ourselves (Kemna, 2017). In addition, due to the fast-growing demand on skin care, Indonesia is projected to be one of the 10 global skin care market (Kemna, 2017). This means Indonesia is a promising market for cosmetics and personal care indsutry which further can be associated to be the pollutant contributors that harm the environment.

The Body Shop ${ }^{\circledR}$ is known of its positive and strong values toward sustainability (Kemna, 2017). This company has implemented green marketing mix strategy (Green Product, Green Place, Gren Price, and Green Promotion ) for a long time as a tool to support sustainable business. As a result, it could run its business but at the same time it also being responsible to the environment. Through this research, the researcher would like to analyze whether the implementation of green marketing mix (Green Product, Green Place, Green Price, and Green Promotion) in The Body Shop ${ }^{\circledR}$ are positively influence the consumers purchasing intention or not (Mahmoud, 2018).

In terms of geographical scope, this study will be focused on Jakarta Region. This decision is taken because in 2017 there are 153 The Body Shop ${ }^{\circledR}$ stores in Indonesia, which located in malls of 39 cities, in which almost half of the total stores are in Jakarta region, while the rest are spread in the other 38 cities (Kemna, 2017). This means that the sales is centralised in Jakarta region and it contributes the highest sales to The Body Shop® Indonesia. As for the consumers age range itself, it will be limited to the young adult. State Adulescent Health Resource Center defines young adult as those who are in the range of 18 to 24 years old (Teipel, 2017) or equal to those who born in 1994 to 2000 (as per 2018). This category is actually also included as a part of new millenial generation, as Kemna stated that those who are born within 1980 to 2000 are defined as millenials.

\section{Green Marketing}

The word 'green' in green marketing refers to the meaning of less harm to the environment or environmentally-friendlier (A., Hung, Ho, \& Sitohang, 2015). So, green marketing can be defined as a promotion or advertising strategy in environmental-friendly manner. However, Polonsky believed that green marketing is a broader concept, which can be applied in industrial and/or consumer goods and services (Davari \& Strutton, 2014). Green marketing is designed to 
provide facilities for the consumers to meet their wants or needs to contribute or involve in environmental issues (Kalsi \& Singh, 2015).

Manongko \& Kambey stated that green marketing itself is an approach that is used to stimulate the company's acivities from planning to the distribution activity in an environmentally-friendly manner (Manongko \& Kambey, 2018). This strategy is a part of promotional practice, to show the company's compliance and concern for the society, with the purpose of shaping the consumer behavior towards the brand (FuiYeng \& Yazdanifard, 2015). Green marketing is closely related to the measuring activity on which the marketing activities will bring positive or negative impacts on environmnet, such as pollution, energy and non-energy resource depletion; protect the natural environment (Davari \& Strutton, 2014).

\section{Green Product}

Green product means that the product is harmless to the environment or environmentallyfriendlier. Specifically, the product must protect the environment by reducing the emission or material consumptions which potentially harming the environment. (A., Hung, Ho, \& Sitohang, 2015). A product can be called as a green product if it is conscious and aware about the environmental impact resulted from its whole life-cycles process. In other words, green product can be define as those products or services which do not overconsume the natural resources and do not cause any harm or bring toxic to the environment (Mahmoud, 2018). In addition, those products which are not excessing the usage of resources and produce immoderate litters, as well as causing severity to animals can also called as green product (Manongko \& Kambey, 2018). Basically, assessment on the product's label and packaging can be used as a measurement of a green product.

\section{Green Place}

Green place is ditribution with the intention to reduce and minimize the carbon footprint resulted from the transportation and logistics activity (Mahmoud, Ibrahim, Ali, \& Bleady, 2017). From this definition, green place can be shown through two ways, which are the green distribution or logistics activities within the company. Green distribution can be defined as an action to reduce the carbon emissions produced by the transportations, so that it will be less harming for the environment (FuiYeng \& Yazdanifard, 2015). There are a lof of things that can be done in order to reduce the carbon footprint, for example licensed an import product for the local production (Solaiman, Osman, \& Halim, 2015). Similarly, Kalsi and Singh define green distribution as an activity of maintaining the green product availability in the right time and place based on the consumers' demand in an effective ways (Kalsi \& Singh, 2015).

On the other hand, green logistics refers to the activity of handling the disatance, which covers all logistic process start from the procurement to the disposition. In green logistics, the company should consider the place and time to obtain the product so that the green product is obtainable by the consumers (Mahmoud, 2018). Green logistics also contains reverse activity in the distribution systems; post-consumers' recycling activities, to extract and reuse the diposed products. This reverse systems will makes some 'role changes' within the chains, where the consumers will be the seller while the manufacturer/company become the buyer (Kinoti, 2011).

\section{Green Price}

Green products are very considerate about its socio-economic environment. An externalization of socio-environmental cost should be done as a result of the internalization of environment within the firm. In other words, premium price should be paid by the consumer in order to obtain the 
green product due to the higher production cost (Peattie \& Crane, 2005). Thus, green price is the acceptable premium price that created due to the additional value provided by green products (Mahmoud, Ibrahim, Ali, \& Bleady, 2017). In implementing green marketing, company should be able to stress on the promotions, such as shows the company's efforts towards green practice or the benefit for consumers, to rationalize the premium price (FuiYeng \& Yazdanifard, 2015).

Basically the consumers are given the option whether to buy the conventional and cheaper product that damaged the environment, or pay a bit higher green product that considered as a environmentally-friendlier product (Kinoti, 2011), fortunately, green consumers are usually aware of the advantageous brought by green products, such as the ability to preserve the planet and humans' health (Mahmoud, 2018), so that they are choosing and willing to pay more for it (Solaiman, Osman, \& Halim, 2015). In short, green consumer has a different (positive) perception towards green product, which creates a willingness to pay premium price to get the product (Mahmoud, 2018).

\section{Green Promotion}

Green promotion is also known as green advertising. It is used to provide information, evidence, and reasoning to the consumer related to the green product; features, and green price so the consumer is interested to the green product (Fui Yeng \& Yazdanifard, 2015). It is a way used to appeal the green consumers which are having a concern to the environment, ecology, and health (Kalsi \& Singh, 2015). In short, geen promotion refers to the advertising activity that intended to influence and appeal the customer to buy and use green products and to encourage the customer to make an environmental commitments (Mahmoud, Ibrahim, Ali, \& Bleady, 2017).

Green promotion is more likely to the way of how a company promote their product but also benefiting the environment. This marketing mix refers to the promoting activity that is harmless for the environment and should be able to help the society to gain more information regarding to the environmental issues that the company engaged in (Kinoti, 2011), for example are the environmental sponsorship or minor changes on the products to make it environmentallyfriendlier. In other words, these activities can be called as environmental communication (Mahmoud, 2018). Solaiman, Osman, and Halim (2015) found that The Body Shop is one of the most successful company that implemented green promotion.

\section{Purchase Intention}

Purchase intention is the consumer willingness to buy a product (Kotler \& Keller, 2012). By knowing the purchase intention, researcher will be able to determine the probability whether the consumer will buy or not buy the product in the future. There are two types of purchase intention, which are positive purchase intention and negative purchase intention. Positive purchase intention is the intention that will followed by actual buying activity, while the negative purchase intention will not (Mahmoud, Ibrahim, Ali, \& Bleady, 2017). Spears and Singh define purchase intention as a purchase plan that was made by the consumer consciously (A., Hung, Ho, $\&$ Sitohang, 2015).

A purchase intention is made through a deliberation process to solve the problem, which results in planned purchase. Buying intention can be measured through the willingness of the consumer to buy, such as probably will buy or definitely will buy the product (A., Hung, Ho, \& Sitohang, 2015). This means that a greater the willingness will lead into a greater possibility to buy the product, while the lower the willingness to buy, the lower also the possibility to buy (Wang, 
Chen, \& Chen, 2016). It shows that purchase intention does not always ends with a buying action.

Similarly, green purchase intention can be defined as a specific green action done by the consumer to show their concern about the environment. Further, green purchase intention means that there are several specific green features that the consumer seeks as a comparison to the conventional products (Muhammad \& Ratnasari, 2014). Muhammad and Ratnasari also stated that studies has shown that intention is a strong predictor of green purchasing decision which will strengthen the possibility to purchase the product (Muhammad \& Ratnasari, 2014).

\section{METHODOLOGY}

Research design is the inquiry within methodological approaches that provide a specific guideline or direction on how to do the research (Creswell, 2012). In this research, quantitative method of conduction and non-experimental design (survey) is being used. Quantitative method underlines an objective measurements and numerical, mathematical, or statistical analysis of data by manipulating pre-existing statistical data using computation techniques (Babbie, 2010). This method use a deductive way of drawing conclusion to generalize and replicate the findings in the research (Creswell, 2012). Thus, it can be seen that close-ended questions will be used as it is the most proper type of question that can be used to generate a large amount of useful data.

To determine the number of sample size, researcher use the sampling method that multiple the number of questions with 5 (Tabachnick \& Fidell, 2007). As there are 31 questions on the questionnaire, so the sample size for this research will be 31 × $5=155$ respondents. While in analyzing the data, multiple regression analysis is chosen as it enables the researcher to predict the changes in dependent variable if two or more independent variables are being manipulated (Sugiyono, 2007).

\section{RESULT AND DISCUSSION}

\section{Validity and Reliability Test}

Validity test was done by using SPSS ver. 25. This test aims to know whether the questions that being used in the questionnaire are valid or not to represent the variables. There were 30 repondents who participated on this test, and the result is range of $0.489-0.871$, its mean that all of the question was valid because bigger than 0.361 (Ghozali, 2011).

Another pre-test that should be done is reliability test. This test is used to know the level of reliability of the questions that being used in the questionnaire. There were also 30 respondents who participated on this test and the result was calculated by using SPSS ver.25. The result of reliability test show that s of Product, Price and Place are acceptable $(>0.7-0.8)$ and variables of Promotion and Purchase Intention are Good (>0.8-0.9) (Ghozali, 2011).

\section{Respondents Profile}

Based on the Figure 1, it can be seen that most of the respondents are female. The pie chart shows that 120 out of 155 respondents $(78 \%)$ are female and the rest 35 respondents $(22 \%)$ are male. The majority of the respondents are $>20-22$ years old with 71 respondents (58\%), followed by 18-20 years old with 35 respondents (23\%), and lastly,>22- 24 years old with 29 respondents (19\%). By educational background, the majority are having senior high school as their education background, which consists of respondents 76 (49\%), followed by Bachelor with 
71 respondents (46\%), and Diploma with 8 respondents $(5 \%)$. The occupation of respondents most of are students. It shows that there are 112 students (76\%), 33 employees $(21 \%)$, and 5 (3\%) respondent are entrepreneurs.

Table 1. Respondents Profile

Source : Questionnaire, 2019

\begin{tabular}{lcc}
\hline \multicolumn{1}{c}{ Demographic } & Total & Percentage \\
\hline Gender : & & \\
Male & 35 & $22 \%$ \\
Female & 120 & $78 \%$ \\
\hline Age : & & \\
$18-20$ & 35 & $23 \%$ \\
$>20-22$ & 71 & $58 \%$ \\
$>22-24$ & 29 & $19 \%$ \\
\hline Education Background : & & \\
Senior High School & 76 & $49 \%$ \\
Diploma & 8 & $5 \%$ \\
Bachelor & 71 & $46 \%$ \\
\hline Occupation : & & \\
Student & 112 & $76 \%$ \\
Employee & 33 & $21 \%$ \\
Entrepreneur & 5 & $3 \%$ \\
\hline
\end{tabular}

\section{Descriptive Analysis}

Table 2 is representing the mean and standard deviation of each gender. From the table, it can be interpreted that the highest mean for the male group comes from $\mathrm{X}_{1}$ green product with 4.137, followed by $\mathrm{X}_{4}$ green promotion with $4.098, \mathrm{X}_{2}$ green price with 4.093 , and $\mathrm{X}_{3}$ green place with 3.877. While for the female group, the highest mean comes from $\mathrm{X}_{2}$, which is green price, with the value of 4.165 . Followed by $\mathrm{X}_{4}$ green promotion, $\mathrm{X}_{1}$ green product, and $\mathrm{X}_{3}$ green place with the value of $4.081,4.076$, and 3.771 . Thus, the variable that dominated by agree and strongly agree answer is green product for male group and green price for female.

Table 2. Gender Descriptive Data

Source: (Questionnaire, 2019)

\begin{tabular}{ccccc}
\hline Variable & \multicolumn{2}{c}{ Male } & \multicolumn{2}{c}{ Female } \\
\cline { 2 - 5 } & Mean & SD & Mean & SD \\
\hline Green Product & 4.137 & 0.534 & 4.076 & 0.543 \\
\hline Green Price & 4.093 & 0.613 & 4.165 & 0.497 \\
\hline Green Place & 3.877 & 0.529 & 3.771 & 0.590 \\
\hline Green Promotion & 4.098 & 0.588 & 4.081 & .0592 \\
\hline Purchase Decision & 4.080 & 0.496 & 3.863 & 0.713 \\
\hline
\end{tabular}

\section{T-Test}

After processing the primary data by using SPSS ver. 25, researchers got the result as follows, Green Product $(X 1) t_{\text {count }}=1.975$, Green Price $(X 2) t_{\text {count }}=2.947$, Green Place $(X 3) t_{\text {count }}=3.362$, Green Promotion (X4) $t_{\text {count }}=3.196$, while the $t_{\text {table }}$ shows the value of 1.645. In another words,

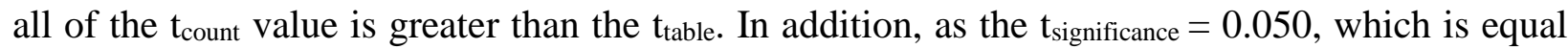


to the sig. value of 0.050 . Thus, researchers can conclude all of independent variables significant influence on Purchace Intention.

Table 3. Result of T-Test

Source: (Questionnaire, 2019)

\begin{tabular}{|c|c|c|c|c|c|c|c|c|}
\hline \multicolumn{9}{|c|}{ Coefficients $^{\mathrm{a}}$} \\
\hline & & \multicolumn{2}{|c|}{$\begin{array}{c}\text { Unstandardized } \\
\text { Coefficients } \\
\end{array}$} & \multirow{2}{*}{\begin{tabular}{|c|} 
Standardized \\
Coefficients \\
Beta
\end{tabular}} & \multirow[b]{2}{*}{$\mathrm{t}$} & \multirow[b]{2}{*}{ Sig. } & \multicolumn{2}{|c|}{$\begin{array}{c}\text { Collinearity } \\
\text { Statistics }\end{array}$} \\
\hline \multicolumn{2}{|c|}{ Model } & B & Std. Error & & & & Tolerance & VIF \\
\hline \multirow{5}{*}{1} & (Constant) & -2.454 & 2.434 & & -1.008 & 0.315 & & \\
\hline & $\mathrm{A}$ & 0.211 & 0.107 & 0.145 & 1.975 & 0.050 & 0.591 & 1.691 \\
\hline & $\mathrm{B}$ & 0.337 & 0.114 & 0.223 & 2.947 & 0.004 & 0.554 & 1.806 \\
\hline & $\mathrm{C}$ & 0.350 & 0.104 & 0.256 & 3.362 & 0.001 & 0.548 & 1.825 \\
\hline & $\mathrm{D}$ & 0.338 & 0.106 & 0.253 & 3.196 & 0.002 & 0.509 & 1.964 \\
\hline & 8 & & & & & & & \\
\hline
\end{tabular}

\section{F-Test}

Table 4 shows $F_{\text {count }}=41.051$, which is greater than the $F_{\text {table }(0.05,4,150)}=2.371$, and the $p$-value $=$ 0.000 , which is smaller than the significant value $=0.050$. This means there is a significant simultaneous influence of Green Marketing Mix; which consists of Green Product, Green Price, Green Place and Green Promotion, towards consumers' Purchase Intention.

Table 4. Result of F-Test

Source: (Questionnaire, 2019)

\begin{tabular}{|c|l|r|r|r|r|c|}
\hline \multicolumn{7}{|c|}{ ANOVA $^{\mathbf{a}}$} \\
\hline \multirow{2}{*}{ Model } & $\begin{array}{c}\text { Sum of } \\
\text { Squares }\end{array}$ & df & $\begin{array}{c}\text { Mean } \\
\text { Square }\end{array}$ & F & Sig. \\
\hline \multirow{3}{*}{1} & Regression & 1801.04 & 4 & 450.26 & 41.051 & $.000^{b}$ \\
\cline { 2 - 7 } & Residual & 1645.26 & 150 & 10.968 & & \\
\cline { 2 - 8 } & Total & 3446.3 & 154 & & & \\
\hline
\end{tabular}

a. Dependent Variable: E

b. Predictors: (Constant), D, C, A, B

\section{Multiple Regression}

According to the table 3, the Multiple Regression formula for this research can be written as follows:

$$
Y=-2.454+0.211 X 1+0.337 X 2+0.350 X 3+0.338 X 4
$$

Where,

$\mathrm{Y} \quad=$ Purchase Intention

$\mathrm{X} 1=$ Green Product

$\mathrm{X} 2=$ Green Price

$\mathrm{X} 3=$ Green Place

$\mathrm{X} 4=$ Green Promotion

Further, the Table 3 also implies that:

1. $\mathrm{X}_{1}$ (Green Product) is significantly influencing the consumers' purchase intention as it's coefficient of regression $=0.050$ is equal to the $\alpha=0.050$. The beta coefficient value of 
this variable means that consumers' purchase intention will increase by $21.1 \%$ for every $1 \%$ increase of Green Product.

2. $\mathrm{X}_{2}$ (Green Price) is significantly influencing the consumers' purchase intention as it's coefficient of regression $=0.004$ is less than the $\alpha=0.050$. The beta coefficient value of this variable means that consumers' purchase intention will increase by $33.7 \%$ for every $1 \%$ increase of Green Price.

3. $\mathrm{X}_{3}$ (Green Place) is significantly influencing the consumers' purchase intention as it's coefficient of regression $=0.001$ is less than the $\alpha=0.050$. The beta coefficient value of this variable means that consumers' purchase intention will increase by $35.0 \%$ for every $1 \%$ increase of Green Place.

4. $\mathrm{X}_{4}$ (Green Promotion) is significantly influencing the consumers' purchase intention as it's coefficient of regression $=0.002$ is less than the $\alpha=0.050$. The beta coefficient value of this variable means that consumers' purchase intention will increase by $33.8 \%$ for every $1 \%$ increase of Green Promotion.

\section{Coefficient of Correlation ( $R)$ and Coefficient of Determination $\left(\mathbf{R}^{\mathbf{2}}\right)$}

Table 5 representing the calculation of $\mathrm{R}$ and $\mathrm{R}^{2}$ that has been done by using SPSS ver. 25 . This table implies that there is a strong correlation between dependent and independent variables within the research. It is shown by the value of $\mathrm{R}$ Square or coefficient of determination, 0.523 , which is much higher than the significant value, 0.050 . In addition, the value of Adjusted $\mathrm{R}^{2}$ is 0.510, which means that the independent variables (Green Product, Green Price, Green Place, and Green Promotion) contribution to dependent variable (purchase intention) is $51.00 \%$, while the rest $49.00 \%$ is influenced by other variables that are not being assessed in this research.

Table 5. Coefficient Correlation and Determination Source: (Questionnaire, 2019)

\begin{tabular}{|c|r|r|r|c|}
\hline \multicolumn{5}{|c|}{ Model Summary } \\
\hline Model & R & R Square & $\begin{array}{c}\text { Adjusted R } \\
\text { Square }\end{array}$ & $\begin{array}{c}\text { Std. Error } \\
\text { of the } \\
\text { Estimate }\end{array}$ \\
\hline 1 & $.723^{\mathrm{a}}$ & 0.523 & 0.510 & 3.31186 \\
\hline
\end{tabular}

a. Predictors: (Constant), D, C, A, B

b. Dependent Variable: E

\section{CONCLUSION AND RECOMMENDATION}

The result of this research conclude that each Green Marketig Mix (Green Product, Green Price, Green Place and Green Promotion influence on customer Purchase Intention. This result inline with Mahmoud (2018); Mahmoud, Ibrahim, Ali, \& Bleady (2017); Manongko \& Kambey, (2018). While, according to Chalimatuz, Nur, and Kusuma's research, green marketing strategy is significantly influence customers' purchase intention as it could help the company to create a good brand image for their green products (Chalimatuz, Nur, \& Kusuma, 2017). Similarly, a study also stated that purchase intention is both direct and indirectly (through brand image) affected by green marketing strategy (Wang, Chen, \& Chen, 2016).

By simultaneously the Green Marketing Mix also influence on customer Purchase Intention. However, the biggest contribution is Green Place, its mean that if the product has the good distribution, the Purcahse Intention will be increase. The millenials as the an environmentally 
conscious age group, can be enriched in designing an eco-friendly product in a unique way that has been implemented by the body shop, where each bottle or jar will return a number of points that can be collected for product exchange. In Jalandhar Region, consumers' purchase intention is driven by the green promotion. This promotion enables them to realize the value-added given by green products, thus they are willing to pay for the premium price (Kalsi \& Singh, 2015).

Contrary, Sentot, Wen-Shai, Shu-Hsun, and Posmaria found out that basically consumer does not concern about the company green marketing strategy. For them, green marketing strategy is merely a promotional activity to advertise the product. Still, the overall study shows that green marketing is positively and significantly influence the attitude of the consumers' perception (A., Hung, Ho, \& Sitohang, 2015).

Through this study, the company should be able to see that basically all aspects in green marketing mix (Green Product, Green Price, Green Place, and Green Promotion) are having a significant influence towards consumers' purchase intention on The Body Shop ${ }^{\circledR}$ products. Thus, the company should pay more attention on this aspects as it plays the biggest role in influencing the consumers' purchase intention towards their products. Specifically, the company could maintain the green place and premium price to let the green image stays on the product, but also balance it with the promotional strategy to increase the purchase intention of the consumers.

For the future researcher who will take this topic, it would be better if the researcher could broaden the population and sample, also the scope of area. Thus, a better and more precise data can be collected. Further, researcher may also find out any other related variables to be assessed, as it could be seen that there are many other variables besides those that have been assessed on this study that contributes $49 \%$ to the influence towards consumers' purchasing intention.

\section{REFERENCES}

A., S. S., Hung, W.-S., Ho, S.-H., \& Sitohang, P. S. (2015). Influence of Green Marketing toward Purchase Intention of Green Products through Attitude: Survey on Indonesian and Taiwanese Students. International Journal of Humanities and Management Sciences, Vol. 3, Issue 4 , 198-202.

Babbie, E. R. (2010). The Practice of Social Research 12th Edition. Belmont, CA: Wadsworth Cengage.

Bogut, M. (2016, March 12). Beauty Products \& Their Impact on Health and The Environment. Retrieved October 24, 2019, from greenspirit: http://greenspirit.com/beauty-environment/

Chalimatuz, Nur, K., \& Kusuma, R. (2017). The Effect of Green Marketing Through Corporate Social Responsibility and Brand Image on the Purchase Intention of The Body Shop Customers in Malang. Russian Journal of Agricultural and Socio-Economic Sciences , 212-222.

Creswell, J. W. (2012). Research Design; Qualitative, Quantitative, and Mixed Methods Approaches - 4th ed. Los Angles: SAGE.

Davari, A., \& Strutton, D. (2014). Marketing Mix Strategies for Closing The Gap Between Green Consumers' Pro-Environmental Beliefs and Behaviors. Journal of Strategic Marketing , 1-24.

EPA. (2017, August 9). Overview of Air Pollution from Transportation. Retrieved October 25, 2019, from United States Environmental Protection Agency.

Erixon, F. (2018, January). The Economic Benefits of Globalization for Business and Consumers. Retrieved January 23, 2020, dari European Centre for International Political Economy. 
Yeng, W., \& Yazdanifard, R. (2015). Green Marketing: A Study of Consumers' Buying Behavior in Relation to Green Products. Global Journal of Management and Business Research, Vol. 15 Issue 5 , 17-23.

Ghozali, I. (2011). Aplikasi Analisis Multivariate dengan Program SPSS (5th ed.). Semarang: Badan Penerbit Universitas Diponegoro.

Jing, H., \& Songqing, L. (2011). The Research of Environmental Costs Based on Activity Based Cost. Procedia Environmental Sciences $10,148$.

Kalsi, P. S., \& Singh, D. I. (2015). Impact of Green Marketing Mix on Consumers' Purchase Behaviour: A Study in the Jalandhar Region of Punjab. International Journal of Engineering and Management Research, Vol. 5, Issue-1, 267-272.

Kemna, L. (2017, January 1). The Body Shop Indonesia: How Can The Body Shop Indonesia Better Engage the New Millenial Generation? Retrieved January 23, 2020, Run Repositorio Universidade Nova.

Kinoti, M. W. (2011). Green Marketing Intervention Strategies and Sustainable Development: A Conceptual Paper. International Journal of Business and Social Science Vol 2 No.23, 263-272.

Kotler, P., \& Keller, K. L. (2012). Marketing Management 14E. New Jersey: Pearson Education.

Mahmoud, T. O. (2018, December 20). Impact of Green Marketing Mix on Purchase Intention. International Journal of Advanced and Applied Sciences , 127-135.

Mahmoud, T. O., Ibrahim, S. B., Ali, A. H., \& Bleady, A. (2017). The Influence of Green Marketing Mix on Purchase Intention: The Mediation Role of Environmental Knowledge. International Journal of Scientific \& Engineering Research, Volume 8, Issue $9,1040-1048$.

Manongko, A. C., \& Kambey, J. (2018). The Influence of Green Marketing on Decision Purchasing Organic Products with Interests of Buying as an Intervening Variable at Manado City, Indonesia. International Journal of Scientific Research and Management, Vol. 6 No. 05 , 403-411.

Peattie, K., \& Crane, A. (2005). Green Marketing: Legend, Myth, Farce, or Prophecy? Qualitative Market Researach: An International Journal Vol. 8 No. 4 , 357-370.

Riskesh Muhammad, J. I., \& Ratnasari, N. G. (2014). Analisis Pengaruh Environmental Knowledge, Environmental Attitude, Government Initiative, Peer Pressure dan Eco Label pada Green Purchase Intention Konsumen Indonesia. Retrieved October 20, 2019.

Solaiman, M., Osman, A., \& Halim, M. S. (2015). Green Marketing: A Marketing Mix Point of View. International Journal of Business and Technopreneurship Vol. 5, No. 1, 87-98.

Sons, T. (2017, March 24). Sustainability Attracts More Customers. Retrieved January 25, 2020, from Thrive Global.

Sugiyono. (2007). Statistika untuk Penelitian. Bandung: Alfabeta Bandung.

Tabachnick, B., \& Fidell, L. (2007). Using multivariate statistics (5th ed.). Boston: Pearson/Allyn and Bacon.

Teipel, K. (2017). Understanding Adolescence: Seeing Through A Developmental Lens. Adolescent Development Research, 1-2.

Wang, Y.-H., Chen, S.-T., \& Chen, N.-N. (2016). An Empirical Study of the Effect of Green Marketing on Purchase Intention - Evidence from Green Restaurant. Advances in Management \& Applied Economics, Vol. 6 No. 4 , 1-14. 